\title{
A importância da tragédia na arte moderna
}

\author{
The importance of tragedy in modern art
}

Felipe Sá Cavalcante Alves ${ }^{1}$

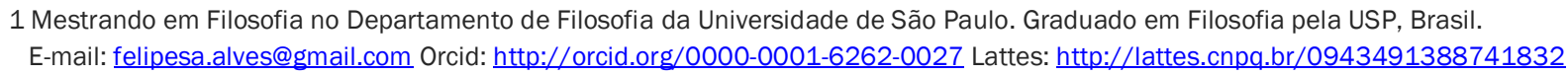

RESUMO: Pretendemos neste artigo analisar a relação entre tragédia antiga e moderna tal qual se apresenta na obra $\mathrm{Ou}$-Ou, de Kierkegaard. Assim, analisando o conceito de tragédia na antiguidade e sua mudança na modernidade, afigura-se como problema mostrar de que maneira a reflexão acerca do trágico aponta uma condição para que a arte moderna tenha significado. Levando em conta, então, que a tragédia antiga é caracterizada pela ação no seio do Estado, da família e da religião e que, por outro lado, a tragédia moderna é determinada pela reflexão, procura-se mostrar que o pesar ligado à ação e suas consequências, torna-se angústia ligada à reflexão e à possibilidade de uma vida trágica. Para tal, primeiro analisa-se o conceito de tragédia antiga e moderna de acordo com o exposto por Hegel em seus Cursos de Estética, desse modo, pode-se melhor ver de que modo Kierkegaard se apropria do exposto por Hegel, mas também de que maneira diverge deste. Isto feito, será possível ver que enquanto Hegel vê na tragédia uma reconciliação das forças opostas, Kierkegaard acentua o caráter esteticamente ambíguo da mesma, afastando-se de qualquer reconciliação. E que, ao assim fazê-lo, indica que a arte moderna só ganha significado com o renascimento do trágico na modernidade.

Palavras-chave: Trágico, Pesar, Angústia.

ABSTRACT: In this article, we intend to analyse the relation between ancient and modern tragedy such as it is presented in the work Either/Or by Kierkegaard. A problem arises when analysing the concept of tragedy in ancient times and how it has changed with modernity; the problem now is to show that the reflection around the tragic point towards a condition for the modern art to acquire meaning. Thus, taking into consideration that tragedy is characterized by action within the realms of the State, Family and Religion and that in contrast, modern tragedy is determined through reflection, we try to show that the sorrow connected with action and its consequences in Greek tragedies becomes anxiety connected to reflection and to the possibility of a tragic life. Therefore, first we analyse the concept of ancient and modern tragedy in relation to what is developed in Hegel's Aesthetic Lectures. In this way, we can better see in what way Kierkegaard appropriates what is shown by Hegel but also in what manner he differs from him. Once this is done, it will be possible to see that while Hegel sees in tragedy a reconciliation of opposing forces, Kierkegaard accentuates the aesthetically ambiguous characters of it, departing from any reconciliation. And in so doing, Kierkegaard indicates that modern art only gains meaning with the rebirth of tragedy in modernity. This indicates that the actual state of the art is ambiguous, having a current state and also a possible one.

Keywords: Tragedy, Sorrow, Anxiety.

\section{A tragédia em Hegel}

Das considerações de Hegel a respeito da tragédia, nos interessa, para nosso presente propósito, 
apenas o exposto em seus Cursos de Estética ${ }^{1}$, desconsiderando o que é dito sobre o assunto em outras obras, como a Fenomenologia do Espírito. E mesmo nos Cursos, nos interessa apenas o que é dito sobre a importância da ação e o que dela decorre na tragédia grega, bem como o que diz respeito à compaixão. Para, na segunda parte do presente texto, ver como Kierkegaard dialoga com as ideias de Hegel.

A tragédia antiga e a moderna são analisadas por Hegel na parte dedicada à poesia dramática, que seria a junção dialética da poesia épica e lírica. A tragédia grega, assim, seria uma parte do desenvolvimento da poesia dramática, considerada por Hegel mais substancial que o drama moderno. A poesia dramática contém um aspecto fundamental da poesia épica e lírica, ao mesmo tempo em que delas diferencia-se. Assim, a epopeia nos apresenta a totalidade de uma ação em que o equilíbrio entre a subjetividade do agente e das circunstâncias exteriores é mantida, isto é, na epopeia a objetividade é um elemento central, pois ainda que haja um agente, a objetividade do mundo exterior é o relevante, determinando e limitando as suas ações. Na poesia lírica, por outro lado, o que impera é a subjetividade do sujeito frente ao mundo exterior, isto é, o sujeito expressa-se a si mesmo e sua interioridade que já não é mais regulada pelo mundo exterior, mas é autônoma.

A poesia dramática, por sua vez, deve apresentar uma ação, importa nela ver a ação dos heróis, porém diferente da poesia épica, nela deve imperar não mais a objetividade exterior, e sim o sujeito que age conscientemente. Por outro lado, mais uma vez, a subjetividade do sujeito não deve ser representada ao modo da poesia lírica, isto é, não deve ser representada passivamente cantando suas paixões, alegrias e gozos, mesmo que sua subjetividade prevaleça, ela deve ser representada por meio de ações. Esse elemento da poesia dramática foi perfeitamente resumido por Hegel, quando diz que "o acontecimento não aparece então surgindo das circunstâncias exteriores, e sim do querer e do caráter interiores e alcança significado dramático apenas por meio da relação com os fins e as paixões subjetivos” (HEGEL, 2004, p. 202). Condensando assim a poesia dramática e a sua relação dialética com a poesia épica e lírica, o trecho citado introduz um elemento ainda não mencionado. Aí é dito que o acontecimento ganha significado dramático através da relação com os fins e paixões subjetivos, e isso é de extrema importância para Hegel, pois na poesia dramática o interior é determinado pela vontade que exterioriza-se em forma de ação, ação que mantém relação com o mundo exterior. Tal ação carrega um fim em si a o representa, por isso a ação no drama leva à colisão, ao embate entre duas potências que agem com fins opostos.

Assim, uma ação só é propriamente dramática quando a sua finalidade e seu conteúdo suscitam fins e paixões opostos em outros indivíduos, uma ação dramática, portanto, deve encontrar obstáculos a sua total efetivação. O verdadeiro conteúdo de uma ação no contexto do mundo grego é aquele que tem impacto e efeito na totalidade da estrutura de uma época, é o que Hegel nomeia de potências eternas, a saber: "o ético em si e para si, os deuses da efetividade viva, o divino e o verdadeiro em geral" (HEGEL, 2004, p. 204). As potências eternas nada mais são, então, do que o divino. Porém, tal como entendido por Hegel, não o divino representado na consciência religiosa, que sempre está em completo repouso, e sim o divino representado através da ação individual e que, nem por isso, deixa de ser o que é: substancial. Entendido desse modo, o divino não pode ser identificado com outra coisa senão o ético. As ações com seus fins são, portanto, o divino representado exteriormente, agindo no mundo e interferindo na totalidade do mundo grego, o que as torna, sobretudo, éticas.

Eis a causa do conflito, as potências éticas não permanecem em repouso, antes estão sujeitas ao princípio da particularização, isto é, se efetivam no pathos humano. Cada agente age com um fim determi-

\footnotetext{
${ }^{1}$ A seguir, citado como Cursos.
} 
nado, do mundo exterior ele acolhe uma parte para sua ação, age por este motivo e não outro, a reação oposta, determinada por outro fim, leva ao conflito. Na tragédia grega cada agente está eticamente legitimado, isto é, agem com razão. Ao agirem afetam outro indivíduo igualmente legitimado, o que faz com que todos, também, sejam igualmente culpados. Legitimados pois são motivados por um pathos cujo conteúdo é substancial, uma potência eterna; culpados porque a substancialidade ética constitui uma totalidade em que todas as partes estão relacionadas, ao perturbarem essa relação, ameaçando o todo, devem ser tomados por culpados e punidos justamente - deve haver uma reconciliação do conflito, uma restauração da relação das partes. O herói trágico age movido por um conteúdo substancial, logo, legítimo; mas ao violar outro agente, torna-se dissidente, seu agir é unilateral, por isso a reconciliação da totalidade ética é requerida, sua harmonia não deve ser ameaçada. Como bem afirmou Martin Thibodeau, os heróis trágicos são "portadores do universal e do substancial [...] e suas ações não são aplicações de regras, de leis exteriores e já dadas, mas sua própria obra, sua própria realização ética” (THIBODEAU, 2015, p. 180); portadores do universal que são, carregam cada um a totalidade em si, de modo que ao atingir outro indivíduo, incorrem em erro por terem em si, de uma só vez, o que defendem e o que atacam.

A reconciliação, ainda que justa e legítima, não deixa de suscitar temor e compaixão, efeitos que, segundo Hegel, e aqui ele segue Aristóteles, a tragédia deve suscitar e purificar. Cada sentimento, aliás, podendo ser sentido de dois modos distintos. O temor pode ser sentido em relação a algo exterior ou finito, porém, o verdadeiro temor é em relação à infinitude, isto é, face à potência ética e ao eterno, que voltase sempre contra quem o ataca. A compaixão pode ser, igualmente, finita, ligada às vicissitudes e à comoção da vida por algum fato qualquer, ou compaixão pela infinitude. A compaixão ligada à finitude não é a que o herói trágico merece, pois suas ações são relacionadas às potências éticas, desse modo, a compaixão deve ser ocasionada pelo fato de que o herói sofre justamente por ter ameaçado romper a totalidade ética, por, ainda que justo, ser ao mesmo tempo culpado e ter de responder por suas ações, conscientes de que merecem sofrer as justas consequências. Segundo Hegel, sobre a compaixão assim entendida, em relação às potências éticas, pairaria o sentimento de reconciliação. Diz ele:

a tragédia garante por meio da visão da eterna justiça, que em seu imperar absoluto perpassa a legitimidade relativa dos fins e das paixões unilaterais, porque ela não pode tolerar que o conflito e a contradição da potências éticas, unas segundo o seu conceito, se imponham vitoriosos na efetividade verdadeira e conquistem consistência (HEGEL, 2004, p. 239).

A reconciliação trágica, assim, é necessariamente sentida pela compaixão que a ação trágica causa no espectador. E um conflito em especial entre duas potências éticas é particularmente o melhor para a representação trágica, já que a harmonia entre elas constitui a existência integral da ética, trata-se do conflito entre o Estado e a família. O Estado seria "a vida ética em sua universalidade espiritual", a família, por outro lado, "a eticidade natural" (HEGEL, 2004, 253). No mundo moderno, o Estado não poderia ser tomado como uma potência ética, pois ele não é mais representado na singularidade, antes, os indivíduos se sujeitam a ele e reconhecem a sua autoridade; ele é regido por leis e costumes e é especializado em cada uma das suas funções, ninguém abarca o Estado como um todo em si mesmo, isto é, a totalidade no mundo moderno seria fragmentada. Não é o caso, nos Cursos, de analisar qual seria o melhor Estado, e sim de ver qual seria o mais adequado ao ideal da arte, que seria o Estado tal qual representado nas tragédias gregas, em que a universalidade e a individualidade ainda se encontram em perfeita união. Na tragédia grega “o ético e o justo devem, portanto, conservar sem exceção forma individual, no sentido de que o ético e o justo dependem exclusivamente dos indivíduos e apenas cheguem neles e por meio deles à vitalidade e 
efetividade" (HEGEL, 2001, p. 194). E se cada indivíduo representa o Estado em sua totalidade, representa em si próprio, também, a outra potência que busca atingir, pois no mundo grego universal e singular são indissociáveis. No conflito entre Estado e família, assim, quem com sua ação aflige o Estado, conteria em si também a totalidade da família e vice-versa. Um bom exemplo é Antígona, de Sófocles, considerada por Hegel a obra de arte a mais satisfatória. Antígona, filha de Édipo, desobedece ao Estado, representando na figura de Creonte, não seguindo a ordem de não enterrar a seu irmão. Agindo desse modo, em nome da sua família, não deixa de viver debaixo das ordens de Creonte. Este, do mesmo modo, por mais que represente o Estado, não deixa de ter uma família, é pai e marido e não deveria deixar de respeitar as leis sagradas no tocante a esta instituição natural. Ambos devem ser vingados um no outro por afrontarem uma potência ética igualmente legítima. É assim que Antígona morre antes de casar-se com Hêmon, filho de Creonte. E Creonte, por seu turno, perde o filho que tira a vida com as próprias mãos por amor a Antígona, e sua esposa, que se entrega à morte por amor ao seu filho.

O mundo da tragédia grega, impreterivelmente, exige a reconciliação como condição de manter a totalidade, a perfeita harmonia e unidade entre universal e individual. Cada agente representa em si próprio, ou antes, é a própria representação de cada uma das instituições, é ele próprio o Estado e a família, o que faz com que cada ação venha a ser necessariamente vingada. Essa harmonia da totalidade também é o que garantirá à tragédia grega a noção de destino. Na modernidade, os fins pretendidos pelo indivíduo não guardam relação com a totalidade, são particularizados - assim como com a noção de Estado, na qual é impossível, no mundo moderno, que seja incorporado em um único indivíduo. Por isso, diz Hegel a respeito do mundo moderno que: "o indivíduo faz o que faz, a partir de sua personalidade, para si como pessoa e responde, por isso, também apenas por sua própria ação, mas não pelo atuar do todo substancial, a quem pertence" (HEGEL, 2001, p. 197-198). O indivíduo que age, assim, responde apenas pela própria ação, não pelas ações, por exemplo, da família. Na tragédia grega, sendo inseparável da totalidade, o indivíduo não é responsável apenas pelas suas ações, é responsável também pelas ações dos pais, não se furta à culpa e à responsabilidade da linguagem da qual pertence. Isso é o que leva à noção de destino: “a ação, o agir e o destino [Schicksal] da família permanecem também a questão própria de cada membro e longe de negar os atos do destino [Geschick] de seus pais, cada indivíduo singular, pelo contrário, os aceita de modo voluntário como sendo seus" (HEGEL, 2001, p. 198).

Quando Antígona conscientemente desobedece ao Estado representado na figura de Creonte e enterra a seu irmão, ela alega assim proceder porque obedece a leis mais antigas, dadas pelos deuses, - por Zeus e pela Justiça (Dikêe) - que, diferente das leis dadas pelos homens, "não são de agora, nem de ontem, mas vigoram desde sempre, e ninguém sabe quando surgiram" (SÓFOCLES, 1992, p. 57). E aqui seguimos a interpretação de Márcia Cristina Ferreira Gonçalves que, apoiando-se no trecho citado e em todo o parágrafo no qual se insere, afirma que, "quando Antígona afirma defender a justiça da Diké, respeita, ao mesmo tempo, a justiça do sangue representada pelas Eríneas, a mesma justiça que determinou, ou melhor, que predeterminou o destino e a culpa de si mesma e de seus irmãos, filhos de Édipo." (GONÇALVES, 2001, p. 286). Desse modo, Antígona aceita seu destino que, de maneira alguma, é indissociável do de Édipo, seu pai - assim, ao mesmo tempo em que honra a lei dos deuses, deve aceitar sua morte ao se sujeitar à justiça de sangue pelas mãos das Eríneas, divindades que representam a vingança, que cobram o cumprimento do destino.

Feita essa breve exposição da tragédia nos Cursos, passemos, então, à exposição e análise que dela faz Kierkegaard em $\mathrm{Ou}-\mathrm{Ou}$. 


\section{Kierkegaard e o trágico}

$\mathrm{Na}$ primeira parte de $\mathrm{Ou}-\mathrm{O} u$, no ensaio intitulado "O reflexo do trágico antigo no trágico no moderno", o pseudônimo A nos oferece uma fina reflexão acerca do conceito do trágico e da tragédia, no qual ao longo de todo o ensaio podemos sentir a influência dos Cursos de Estética de Hegel. Porém, não se trata, a exemplo de Hegel, da oposição entre a tragédia grega e a tragédia moderna para ver o que é próprio de cada uma e de que maneira diferenciam-se, e sim de como a tragédia antiga deixa-se absorver pela tragédia moderna na intenção de devolver à modernidade seu elemento trágico, dado que nela impera o cômico. A influência de Hegel nessa empreitada é sentida de perto, e tendo em vista o exposto anteriormente, ficará mais fácil pontuar em quais momentos Kierkegeaard, sob o pseudônimo de A, difere de Hegel. Também não podemos perder de vista que o diálogo não é somente com Hegel, mas também com Aristóteles, pois por maior que seja a distância - cronologicamente falando - entre a tragédia antiga e a moderna, o conceito dado por Aristóteles permanece verdadeiro, de sorte que um regresso à Poética, segundo A, não é mero capricho ou costume, mas necessário caso se queira pensar a volta do elemento trágico na modernidade.

Contudo, pode-se concordar com Aristóteles de maneira geral sobre o conteúdo do conceito de tragédia, e ainda assim divergir dele em pontos particulares. O mesmo se dá com a comédia, isto é, ninguém negará que a comédia deve suscitar o riso, mas o que era risível na antiguidade certamente não é o mesmo de hoje. Assim, segundo Aristóteles, é "pois a tragédia a mimese de uma ação de caráter elevado" (ARISTÓTELES, 2015, p. 71), porém, o elemento trágico, o que faria da tragédia o que é, pode não ser o mesmo no mundo grego e no mundo moderno. A tragédia grega, e aqui o pseudônimo A segue Aristóteles e Hegel, tem por ponto central a ação, pois por mais que os agentes possuam pensamento e caráter, que são as causas naturais e fatores que qualificam as ações, o mais importante é a ação.

As ações na tragédia, segundo A, ainda que propiciadas pelos agentes, são passivas frente ao elemento substancial contido na objetividade, isto é, mesmo sendo ações escolhidas por aquele que age, não deixam de, ao mesmo tempo, terem certa passividade frente à objetividade exterior, o que lhes confere um caráter ambíguo. Essa passividade é o que confere o elemento trágico às tragédias. Assim, diferente do que ocorre na modernidade, na tragédia grega a subjetividade não se encontra demasiadamente refletida em si e livre de todo vínculo obrigatório com as instituições, pois ainda "que um indivíduo se movesse livremente, repousaria afinal em determinações substanciais no estado, na família, no destino" (KIERKEGAARD, 2013, p. 180), dá onde se vê a influência de Hegel em sua visão da tragédia grega. O elemento trágico, dessa maneira, residiria no conflito surgido entre a ação e a passividade diante das instituições objetivas. Por isso, na tragédia grega o indivíduo não vive isolado, não apenas no sentido de manter relações com as instituições que lhe são exteriores, mas também no sentido de que essa passividade lhe confere um destino. Isto é, seguindo Hegel, Kierkegaard vê como uma das características fundamentais da tragédia grega o fato de que nela o destino se faz senti. Desse modo, Antígona não poderia fugir das consequências das ações do pai, em suma, ela pertence a uma linhagem que determina o seu destino. Mas aqui, ao mesmo tempo, Kierkegaard diverge de Hegel, pois, segundo o filósofo dinamarquês, o que importa para que uma tragédia seja de fato uma tragédia não é que a unilateralidade da ação seja aceita como destino expresso em uma punição eticamente legitimada, e sim que a culpa representada na tragédia seja uma culpa estética, o que quer dizer que ela deve ser anfibológica.

Diferente de Hegel, o elemento ético é que deve ser afastado da tragédia, como bem lembra Clyde Holler (HOLLER, 1995, p. 132-134), pois ao ético diz respeito o mal e o arrependimento, categorias que, 
de fato, aparecem no teatro quando retira-se o elemento trágico a favor da representação isolada do indivíduo que tenta construir um destino para si mesmo por si só. Segundo A, certos temas não encontram lugar ao se considerar uma obra de arte, aí eles estariam deslocados e, por isso mesmo, seriam deformados, e que isso ocorra na modernidade apenas expressa a grande confusão na qual se encontra, pois "procura-se uma coisa onde não haveria de ser procurada e, pior ainda, encontra-se essa coisa onde não haveria de ser encontrada" (KIERKEGAARD, 2013, p. 186). Assim, ao ser representado no drama moderno de forma isolada, sem relação alguma com a sua época, responsável por si próprio e pela criação do seu próprio destino, a culpa do indivíduo não seria mais ambígua. Acontece que, ao despojá-lo de tal ambiguidade, ele passaria a ser representado de acordo com conceitos éticos e religiosos, como, por exemplo, o mal, o pecado e o arrependimento. A perda da ambiguidade estética, do elemento trágico mesmo, faria, então, com que a tragédia almejasse a representar conceitos dos quais ela não tem condição nem de compreender nem de representar, nela se passaria a buscar a edificação ou o interesse psicológico da representação do arrependimento, elementos que, de modo algum, dizem respeito à estética, o que ocasionaria o aprofundamento da modernidade no cômico. Responsável pela criação de seu próprio destino, a culpa no drama moderno é inteiramente do indivíduo, isso, porém, leva à morte do trágico na vida moderna. Como diz A:

Nossos tempos perderam todas as determinações substanciais de família, de estado e de linhagem; têm de deixar o indivíduo completamente abandonado a si próprio, de molde a que, no mais rigoroso sentido, se converta no seu próprio criador, cuja culpa é, portanto, pecado, e cuja dor é arrependimento (KIERKEGAARD, 2013, p. 186).

Não por outro motivo, “a tragédia onde há sofrimento perdeu propriamente o seu interesse trágico, pois o poder do qual provém o sofrimento perdeu a sua significação” (KIERKEGAARD, 2013, p. 186). O sofrimento moderno perde sua significação justamente porque é isolado, refletido dentro do próprio indivíduo, tendo lugar apenas no que A denomina de o palco espiritual. E isso é importante, dado que, conforme A afirma em relação à compaixão, ele acha mais proveitoso, para alcançar o elemento esteticamente trágico da tragédia, analisar a compaixão no que diz respeito a sua diferença quando comparada à culpa trágica - e não proceder ao modo de Hegel tal qual exposto nos Cursos, que considera "a compaixão no universal e a respectiva diferença na diferença da individualidade" (KIERKEGAARD, 2013, p. 184). Colocando o problema dessa maneira, A passa a analisar o pesar e a dor. O pesar não é em si mesmo refletido, ele não ocorre, como A dirá ao se referir à dor moderna, no palco espiritual, por isso ele é mais substancial, já que sua falta de reflexão deve-se a que ele mantém uma relação dialética viva e natural, e não mais abstrata - o que significa dizer que o pesar mantém relações com a família, a linhagem e a religião. A dor, por sua vez, exige uma maior reflexão e, assim, leva ao sofrimento e à culpa individual, isto é, quanto mais isolado em si próprio, tanto mais o indivíduo torna-se responsável pela própria culpa, porém, com isso perde-se o elemento próprio do trágico, a culpa original, anfibológica. A culpa na tragédia grega não está excluída, só não é refletida subjetivamente. É isto o que lhe garante o estatuto de ser a verdadeira culpa trágica: a ambiguidade da ação, a passividade do indivíduo ao mesmo tempo em que age livremente; ser culpado e, ao mesmo tempo, não ser; ser livre e ainda assim estar preso ao destino. A culpa original, verdadeira, é, assim, esteticamente ambígua.

Se à tragédia grega pertence a culpa original, o pesar profundo, A encontra como pertencente ao drama moderno, por sua vez, a dor e o sofrimento acompanhados pela angústia, "órgão através do qual o sujeito se apropria do pesar e o assimila para si” (KIERKEGAARD, 2013, p. 192). Ao drama moderno, como característica distintiva, cabe agora a angústia que se relaciona ou com o tempo passado ou com o 
tempo futuro, pois angustiar-se com o tempo presente é impossível, este passa no instante. Temos, então, um desafio apresentado ao drama moderno a partir do momento em que a angústia lhe determina: como a angústia assimila o pesar para si, uma vez que é, por definição, reflexiva e o pesar, ao contrário, contém um elemento objetivo muito mais forte? Essa, segundo nosso ponto de vista, parece ser a pergunta indireta que permeia a angústia no ensaio a respeito do trágico e o seu uso no desenvolvimento da Antígona moderna.

A Antígona moderna não aceita seu destino com o pesar do qual não pode escapar, sua história não é representada no palco exterior das relações substanciais puramente exteriores - ela sente-se a si mesma em seu palco interior, espiritual. Seus lamentos são internos, em certo sentido, é morta-viva, seu sofrimento internalizado através da reflexão é sua vida e também sua ruína em forma de segredo; segredo o qual não pode contar a ninguém, para preservar a honra e memória de seu falecido pai, Édipo, que não sabia que sua filha era conhecedora da sua história funesta, de que tinha matado o pai e deitado com a mãe. A vida de Antígona passa a ser uma constante dor e sofrimento, identifica-se com a tarefa de guardar seu segredo e sentir-se culpada por ele. Sente-se culpada, mas de modo ambíguo, e aqui A indica a possibilidade da tragédia grega ser absorvida pela moderna. Diz o pseudônimo a respeito de Antígona:

Ela ama o pai com toda a sua alma, esse amor arrasta-a para fora de si própria e para dentro da culpa do pai; como fruto de um tal amor sente-se alheada dos homens, sente tanto mais a sua culpa quanto mais amar o pai, só junto dele encontra repouso; como são igualmente culpados, sentiriam pesar junto um do outro (KIERKEGAARD, 2013, p. 198).

Estes são os termos da possibilidade da retomada do elemento trágico na modernidade, restabelecer os laços atávicos e as relações em geral com o outro, sem desconsiderar a angústia característica dos tempos modernos. Essas condições não são apenas a possibilidade do renascimento do trágico na modernidade o que por si só já é muita coisa - mas é ainda o aprofundamento, ou o levar até os limites, a própria concepção da tragédia grega. A título de exemplo, não podemos deixar de lado que A chega a dizer, ao comparar a Antígona grega a moderna, que aquela "vive assim a vida sem pesares" (KIERKEGAARD, 2013, p. 194). Com essa afirmação, A não retira o que concedeu à tragédia grega - o pesar - mas agora pensa-o de forma a que possa ser assimilado pela angústia, busca, em suma, retomar os laços da atávicos de Antígona, mas agora com a exigência de que este possa ser assimilado pela angústia. Antígona, assim, não pode fugir ao seu destino, herda sua culpa e seu segredo por ser da linhagem de Édipo; sua culpa, porém, não é mais culpa exterior, e sim é internalizada e sentida em cada momento, tornando-se pesar que deve ter lugar no coração do indivíduo. Dessa maneira, o sofrimento pode reganhar sua razão de ser, recuperar novamente seu significado.

A Antígona moderna, assim, é inquieta em seu pesar, isso já a torna suficientemente interessante, resta apenas um conflito para dar a sua nova reestruturação um conflito trágico. O conflito passa a ser então entre sua família e seu amor por Hêmon, filho de Creonte. Ela o ama, mas só pode amá-lo com o seu segredo, com a sua dor e para ela seria um pesar tanto maior entregar-se a ele resguardando aquilo que a machuca. Hêmon, ciente da grande dor de Antígona, insiste em descobrir seu segredo, que ela confia nele e que o ame com um amor semelhante ao que ela tem pelo pai, pois ele também sabe que morreria caso perdesse o amor dela. Antígona, porém, é inseparável da sua culpa, não quer trair ao pai contando seu segredo, que também é o dela, porém também não quer perder a Hêmon, a quem ama. O único modo de entregar-se a Hêmon, de contar-lhe o segredo e amá-lo como ele quer, é deixar de pertencer a ele no mesmo instante em que possa vir a lhe pertencer. Tão íntima de seu segredo, Antígona só pode contar o 
seu segredo à custa da própria vida. Assim, dirá A de toda a situação que: "Os poderes em colisão mantêm-se a par um do outro em tal grau que a acção se torna impossível para o indivíduo trágico” (KIERKEGAARD, 2013, p. 201). O renascimento da tragédia na modernidade, desse modo, ocorre através de uma tensão ainda maior do que aquela gerada pelo conflito dos heróis na tragédia grega, pois na tragédia moderna a assimilação do pesar pela angústia anula qualquer possibilidade de agir e, com isso anula, também, a possibilidade da experiência da liberdade. A assimilação da tragédia grega na tragédia moderna é, portanto, um retorno do trágico até os seus últimos limites. E como bem observa Holler, o trágico é fundado na relação de Antígona com a família e com Hêmon, mas não em um conflito ético, e sim estético, ambíguo (HOLLER, 1995, p. 140).

O estado da arte na modernidade, assim, encontra-se duplamente tensionado. Pode ser visto de dois modos. Ou a arte evita buscar o renascimento do trágico, entregando-se ao cômico e deixando a arte à mercê de conceitos éticos e religiosos; ou almeja o retorno do trágico, pagando o preço de perder totalmente a possibilidade de agir. O ensaio do pseudônimo, como exposto, ignora a primeira possibilidade, lhe interessa, justamente, dar à modernidade alguma substancialidade, fazer com que o sofrimento tenha significado. Todavia, as coisas não são mais fáceis ao se optar, como A, pelo segundo caminho. Isto é, ao excluir a possibilidade da ação na tragédia moderna, e com ela qualquer possibilidade de reconciliação, estaria indicando que uma resolução dos conflitos individuais, no que diz respeito ao segredo, e em relação ao outro, a exterioridade, só é possível no âmbito do religioso. Seguindo este raciocínio, Holler argumenta que "a colisão trágica entre o indivíduo e a comunidade não pode ser resolvida dentro de qualquer esfera, pois as forças são muito niveladas e são resolvidas apenas dentro da estrutura da religião" (HOLLER, 1995, p. 141).

De fato, segundo A, a "unidade, designadamente entre um absoluto sem culpa e a culpa absoluta, não é uma determinação estética, é antes uma determinação metafísica”, pouco mais a frente, no mesmo parágrafo, complementa:

A identidade de um agir absoluto e de uma passividade absoluta é superior às forças da estética e pertence à metafísica. Na vida de Cristo verifica-se esta identidade, pois o seu sofrimento é absoluto porque o seu agir é absolutamente livre, e o seu agir é absoluto sofrimento porque é uma obediência absoluta (KIERKEGAARD, 2013, p. 187).

Interpretando a identidade do agir absoluto e da passividade absoluta um pouco diferente, Daniel Greenspan afirma que o "correto entendimento da tragédia na época moderna, contudo, abre a porta para o “"mais” religioso de Cristo dentro dos textos trágicos circulados pelos estetas" (GREENSPAN, 2008, p. 156). Neste sentido, a verdadeira expressão para o trágico seria dada pelo cristianismo. Greenspan desenvolverá ao longo de seu livro o conceito de tragédia em Kierkegaard, mas seu aprofundamento do conceito se dará baseado em outras obras, de $\mathrm{Ou}-\mathrm{O} u$, pode-se dizer que essa é sua conclusão, arrematando que "Cristo é a ideia trágica à qual sujeitos modernos devem-se submeter a si próprios se o profundo pesar e a profunda alegria da vida humana deve ser recuperada” (GREENSPAN, 2008, p. 157).

Não pretendemos desmerecer ou corrigir o que Holler ou Greenspan concluem sobre a tragédia tal qual exposto no $\mathrm{Ou}$-Ou, isso seria despropositado e não levaria em conta a afirmação de A, quando diz que "uma obra concluída não estabelece nenhuma relação com a personalidade geradora de poesia" (KIERKEGAARD, 2013, p. 189), o próprio ensaio, portanto, permite várias interpretações, carrega em seu bojo sementes que podem dar à luz uma multiplicidade infinda de vozes. Assim, ainda que discordando de algumas considerações dos estudiosos supracitados, pretende-se tão somente oferecer uma interpretação 
diferente, porém, focando apenas no que se relaciona com o estado de arte.

O trágico tal como é tratado no ensaio não exclui o diálogo com o ético e o religioso, esse diálogo, no entanto, é para poder identificar e recuperar o que é essencialmente trágico, e, como pudemos ver, segundo o pseudônimo o essencial é o conflito ambíguo, a anfibologia da ação. Ao reconstruir a peça de Sófocles de modo a lhe introduzir elementos caracteristicamente modernos, A leva a tragédia até ao extremo de modo que, indo além da tragédia grega, exclui a própria possibilidade de agir. Não por outro motivo, Greenspan dirá que com a Antígona moderna "Kierkegaard descreve a experiência moderna de liberdade [...] de tal maneira que o exercício da liberdade se torna uma impossibilidade" (GREENSPAN, 2008, p. 153). Contudo, diferente do que Holler afirma, não há motivos para que a cura do sofrimento de Antígona esteja "na renúncia do trágico e na aceitação do poder curativo da religião" (HOLLER, 1995, p. 142). Isso porque não há motivos para se crer em uma separação total da religião e da estética. De fato, ao analisar a tragédia grega, A afirma que Cristo é a unidade da passividade e da ação absoluta, que sua ação e seu sofrimento são absolutos. Porém, o que não pode ser esquecido é que Cristo é introduzido na discussão justamente para se procurar definir o que seria a culpa trágica original - estética - e não mais ética, ao modo de Hegel. Não obstante, a vida de Cristo é descrita em termos estéticos e religiosos. Isto é, o surgimento de Cristo ocorre na "plenitude dos tempos e carregou o pecado do mundo" (KIERKEGAARD, 2013, p. 179), nisso, todavia, não deixa de ser trágico, pelo contrário, sua vida "é em certo sentido a tragédia mais profunda” (KIERKEGAARD, 2013, p. 179). É a unidade absoluta, e ao ser essa unidade inserese em uma discussão metafísica, mas, ainda assim, não deixa de ser um modelo da culpa estética. Assim, se a estética é incapaz de viabilizar a ação, o que é resolvido no religioso, isto não exclui que a tragédia por excelência - a vida de Cristo - não tenha seu conflito inspirado na tragédia grega e, mais do que isso, constitui-se na sua completude, no seu desenvolvimento pleno. Que Cristo seja a unidade absoluta, o que faz com que deva ser considerado de um ponto de vista metafísico, não exclui que, ainda assim, ele é representado como um conflito trágico por excelência, isto é, parece ser muito mais o caso de que a sua história é inspirada essencialmente nos moldes da tragédia grega, o que faz com que entre religião e arte não haja nenhuma separação. Que Cristo seja a completa realização do estético parece evidente pelo texto, mas daí apreende-se, também, que o religioso não é a recusa do estético, mas sim que a estética é o modelo do religioso. O religioso não seria, portanto, apenas a superação do estético, antes, ambos seriam inseparáveis, e conceitos religiosos dependeriam de um modelo e de uma comunicação estética. A história mais importante do cristianismo, a morte e a ressurreição de Cristo, seria, assim, não apenas inspirada na tragédia grega, seria ela própria uma obra de arte e só pode ser propriamente comunicada através de uma linguagem poética, e só pode ser propriamente compreendida, quando compreendida poeticamente.

Ao propor que a resolução do conflito de Antígona - e junto com ela, de todos os que pretendem agir na modernidade - esteja simplesmente no religioso, considerado como uma instância superior, deixase de lado que a angústia assimila em si o pesar, o que não é apenas consequência de que uma categoria moderna deve se voltar a outra mais antiga, antes, indica que a angústia, enquanto reflexiva, deve ser capaz de assimilar em si um conceito típico da tragédia grega que, ao mesmo tempo, encontra sua máxima aplicação em Cristo. Assim, a arte moderna, ao firmar-se no cômico, encontra-se num estado de arte incapaz de perceber que a sua falta de substancialidade deve-se a que não foi capaz de propor o renascimento do trágico na figura de Cristo, considerando-o através de categorias estéticas.

Desse modo, Cristo ajuda a definir a culpa trágica original porque é ele mesmo a mais perfeita tragédia, é através da sua figura que entende-se não que o religioso é a única esfera possível da dissolução do dilema da liberdade e da ação de Antígona; pelo contrário, ele é a figura que permite ver que a completude 
da estética é tratar o religioso esteticamente, e que este, o religioso, é indissociável de uma comunicação estética, ambígua. Não por outro motivo, temas centrais do cristianismo serão em outra obra, Migalhas Filosóficas, expostos por um poeta. Como a ambiguidade estética se apresenta nesta obra sairia do foco do presente texto. Por isso, cabe observar apenas que o estado da arte moderna, segundo o ensaio da tragédia de A, é o cômico em que não há significado no sofrimento e em que a felicidade é falsa, pois, como diz o pseudônimo, "o indivíduo só é feliz quando possui o trágico” (KIERKEGAARD, 2013, p. 182), contudo, por outro lado, ao estado da arte moderna apresenta-se a possibilidade de recuperar o trágico ${ }^{2}$.

O religioso, portanto, não é a instância superior ao estético, posição adotada por Holler, mas é relacionado com a esfera estética, poética. E ainda que Greenspan afirme que o correto entendimento da tragédia na modernidade não pode ignorar a figura do Cristo, ele deixa de lado que A, em seu ensaio, também aponta para o estado da arte na modernidade e em como este estado detém uma facticidade - o cômico - e uma possibilidade - o renascimento da tragédia. O ensaio, como dito acima, deixa a porta aberta para uma multiplicidade de interpretações, assim, buscou-se no presente artigo apontar para uma delas em específico - o estado da arte. Acontece que a consideração do que é dito a respeito da tragédia, segundo nos parece, deixa transparecer que mesmo a unidade metafísica por excelência, ao relacionar-se com a tragédia, deve ser compreendida como obra de arte. O renascimento da tragédia na modernidade, portanto, é também indissociável da consideração estética da religião, o que não quer dizer, de maneira alguma, que os temas artísticos na modernidade devam ser todos religiosos, o que não ocorre, por exemplo, na tragédia da Antígona moderna. Para entender este ponto, é de grande ajuda lembrar que A afirma que "a riqueza da individualidade consiste exatamente na força de prodigalidade fragmentária” (KIERKEGAARD, 2013, p. 189), porém, ao propor o renascimento do trágico trata-se não da força individual, do fragmentário, e sim de devolver à modernidade a substancialidade, isto é, de ressignificá-la.

Assim, segundo interpretamos, a religião esteticamente entendida é a esfera na qual a totalidade pode ser restaurada. Cristo, nesse sentido, seria a figura religiosa através da qual todos os laços substanciais com o exterior poderiam ressurgir. Desse modo, seria a obra de arte trágica que possibilitaria a todas as outras a sua substancialidade, sem que, por isso, deva ser tema de toda a produção artística.

\section{Considerações Finais}

Com o presente texto, procurou-se expor brevemente a tragédia grega tal qual é entendida por Hegel nos Cursos, isso porque um melhor entendimento do ensaio sobre o trágico de A depende do conhecimento das teses de Hegel. Mas não só por isso, e sim porque ao mesmo tempo em que expõe a influência de Hegel, discorda do filósofo alemão, pois diferente deste busca valorizar não o ético na tragédia grega e moderna, e sim o elemento essencialmente artístico que faz da tragédia o que ela é - uma obra de arte, já que, conforme tentamos mostrar, a preocupação de A ao tratar da tragédia é justamente analisar o estado atual da arte.

Assim, em $\mathrm{Ou}-\mathrm{O} u$ pudemos ver de que modo Kierkegaard buscou mostrar como o ensaio se volta

\footnotetext{
${ }^{2} \mathrm{~A}$ análise de Kierkegaard a respeito da tragédia, o que fica claro durante todo o ensaio, pretende também indicar a retomada de uma existência trágica, que tenha relações substanciais com a família, o próximo, o mundo exterior em sentido amplo e Deus. Temas que são desenvolvidos em outras obras, tais como Duas Épocas: A Época da revolução e a Época presente, O Conceito de Angústia, O Conceito de Ironia e na segunda parte de Ou-Ou, para ficar só nessas. Contudo, se analisássemos a concepção de Kierkegaard da existência como trágica e de como ela, a vida, torna-se obra de arte, sairíamos do escopo do presente trabalho, que pretende focar apenas no que o ensaio do pseudônimo indica a respeito do estado da arte moderna da sua assimilação da tragédia grega.
} 
não à desvalorização do estético e ao reconhecimento do religioso como a esfera máxima da liberdade, e sim que é mostrado uma intersecção profunda entre o estético e o religioso de modo a fornecer um diagnóstico de mão dupla no que diz respeito ao estado da arte na modernidade: o estado atual, fundado no cômico; e o estado possível, que considera esteticamente a vida de Cristo.

Com isso, procurou-se mostrar que Kierkegaard não favorece a religião em detrimento da estética, do poético, ao passo que relaciona as duas para fornecer uma aguda reflexão no tocante à arte moderna.

\section{Referências}

Aristóteles (Publicação original datada aproximadamente no séc. V). Poética. Edição bilíngue. Tradução, introdução e notas de Paulo Pinheiro. São Paulo: Editora 34, 2015.

Greenspan, Daniel. (2008). The Passion of Infinity: Kierkegaard, Aristotle and The Rebirth of Tragedy. Edited on behalf of the Søren Kierkegaard Research Centre by Niels Jørgen Cappelorn and Hermann Deuser. Berlim: Walter de Gruyter.

Gonçalves, Márcia Cristina F. (2001). O Belo e o Destino. Uma introdução à Filosofia de Hegel. São Paulo: Edições Loyola.

Hegel, G.W.F. (1835). Cursos de Estética, Vol. I. Tradução de Marco Aurélio Werle e Oliver Tolle. Consultoria de Victor Knoll. São Paulo: Edusp, 2001.

Hegel, G.W.F. (1835). Cursos de Estética, Vol. IV. Tradução de Marco Aurélio Werle e Oliver Tolle. Consultoria de Victor Knoll. São Paulo: Edusp, 2004.

Holler, C. (1995). Tragedy in the Context of Kierkegaard's Either/Or. In. International Kierkegaard Commentary. Either/Or. Part I. Edited by. Robert L. Perkins. Macon, Georgia: Mercer University Press.

Kierkegaard, Søren A. (1844). Ou-Ou. Um Fragmento de vida (Primeira Parte). Tradução, introdução e notas de Elisabete M. de Sousa. Lisboa: Relógio D’Água, 2013.

Sófocles. (442 A.C). Antígona. Tradução de Maria Helena da Rocha Pereira, Coimbra: Fundação Calouste Gulbekian, 1992.

Thibodeau, Martin. (2015). Hegel e a tragédia grega. Tradução de Agemir Bavaresco e Danilo Vaz-Curado R. M. Costa. São Paulo: É Realizações Editora.

Artigo recebido em: 20 de dezembro de 2019

Artigo aceito em: 02 de março de 2020 